for the homeward voyage. The extraordinary good fortune of the delegation in the matter of weather conditions, culminating in the brilliant hours of the visit to Darjeeling, has been recorded in a previous note. At Calcutta these conditions have continued, and it is said that the mean daily temperature has been as much as ten degrees above the normal for this time of year."

\section{Broadcasting and Citizenship}

AT the North of England Education Conference on January 6 the Central Council for School Broadcasting and the Central Committee for Group Listening were represented by their secretary, Mr. A. C. Cameron, who discussed the principles on which these two bodies are at present shaping their policies and raised a number of questions as to the moulding and educating influences of broadcasting on the citizen of to-morrow and to-day. As regards school broadcasting, for the reception of which, by the way, in England and Wales some 7,000 schools are equipped, he emphasized its importance as fostering the interest of the child in life outside the school and the interest of the parent in the school. As evidence of the growing interest of parents he mentioned that a school broadcast recently brought him three hundred letters from parents who had listened to it. To promote group listening and discussion seven area councils representative of voluntary bodies, local authorities and the universities have been constituted. Many listening and discussion groups have been formed by such bodies as women's institutes, townswomen's Guilds and public libraries, and many are recognized by local education authorities as eligible for grants for "further education". Another speaker at the Conference, a member of the executive of the National Union of Teachers, argued that wireless receiving sets ought to be regarded as essential pieces of equipment for schools and for bodies such as juvenile organization committees and community centres which undertake to promote group listening as a means of adolescent and adult education. It seems open to question whether grants should be made for encouraging such listening and discussion groups without some sort of guarantee that they are conducted by competent leaders. With proper guidance (for which attendance at university extension tutorial classes would provide an excellent training) such groups could be developed into a powerful agency for education for citizenship.

\section{Psychology of International Relations}

IN an address at a public luncheon given by the National Institute of Industrial Psychology on January 13, Dr. William Brown said that the psychology of international relations, otherwise the psychology of peace and war, can be adequately discussed only on the basis of a scientific study of the human mind. Dr. Brown is convinced that the latest war was not the last. He compared it with a manicdepressive patient who, after a state of deep depression, passes into one of exaltation and feels that never again will his old symptoms return. Of a patient of this kind it is known that sooner or later he will have another relapse. Although psychological treatment can benefit such a patient, and in some cases produce recovery, the underlying physical and mental causes of the illness remain obscure. So it is with war and peace. Psychologists cannot yet claim that a solution has been discovered. All they can do is to go on and disentangle the various forces which are at work to produce war. Of these forces, one of the most important is the primitive struggle for existence. It is not possible, however, said Dr. Brown, to deduce the social behaviour of a man from his purely individual behaviour. Man still carries with him tendencies towards more primitive forms of mental reaction such as are appropriate to the early stages of national and social evolution. These primitive forms of reaction are very clearly revealed in criminal behaviour, in panic-stricken flight and in certain mass movements. The possibility of mass mental reactions have an obvious bearing upon the problem of war and peace. For such primitive forces as self-preservation and self-assertion, while valuable in many respects, yet if used in certain ways, are irreconcilable with ultimate peace between individuals or between nations.

\section{Chinese Universities Relief Fund}

THE damage inflicted on universities in the course of the Japanese invasion has been enormous, amount. ing in several instances to complete destruction of all the university buildings and equipment. Concerted action has been taken by students, professors and the Chinese Government to combine the relief of distressed students with the maintenance of some form of training in centres remote from the war theatres, such as Changsha in Hunan Province. Appeals to universities in other lands have been organized by International Student Service for the relief of destitute students and for equipping them in their efforts to carry on their studies. In England there has been a response from every single university and the majority of university colleges, the amount raised in this way up to date being $£ 3,000$. The English committee has undertaken, in addition to contributing to the international fund, to assist Chinese students in Great Britain whose funds have been cut off. In a letter to The Times of January 7, Sir Walter Moberly, chairman of the International

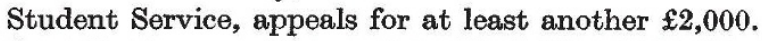
Contributions may be sent to Prof. Ernest Barker, the Hon. Treasurer of the Chinese Universities Relief Fund, at 49 Gordon Square, London, W.C.1.

\section{Determination of Molecular and Atomic Weights}

A commitree for the study of the determination of molecular and atomic weights of gases by physicochemical methods, organized by the International Institute of Intellectual Co-operation assisted by the International Council of Scientific Unions and by the International Unions of Physics and Chemistry, met on December 17 and 18 in Neuchâtel (Switzerland). Two reports formed the basis of the discussion, the first on the method of limiting-pressures, established 
by Prof. R. W. Whytlaw-Gray and Dr. W. Cawood, the second on the method of limiting-densities, established by Prof. E. Moles. Prof. Jaquerod presided over the assembly, which was attended by Profs. Whytlaw-Gray (Leeds), Moles (Madrid), Lepape (Paris), Klemenc (Vienna), Timmermans (Brussels), Keesom (Leyden) and Dr. Cawood (Leeds). Several suggestions were made concerning the improvement of the methods used, and a discussion took place concerning the interpretation of the results obtained. Among the conclusions, the committee emphasized the international importance of the laboratories at Leeds (Whytlaw-Gray) and at Madrid (Moles), on account of the results they obtain, their equipment and the special qualifications of their staffs. This is to be reported to the International Organisation on Intellectual Co-operation of the League of Nations. The full reports and the minutes of the meeting will be published by the International Institute of Intellectual Co-operation. This meeting was a part of the projected scientific activity of the International Organisation on Intellectual Co-operation. Future assemblies of committees of study will be held this year and the following questions will be discussed : "New Vitamins"; "Nomenclature of Genetics"; "New Theories of Modern Physics" ; "Co-ordination of Scientific Terminologies" and "The Electric Double Layer".

\section{Scottish Universities Parliamentary Election}

ON January 20, a writ was issued for the Scottish Universities by-election, made necessary by the death of Mr. Ramsay MacDonald. A group of strong candidates is in the field : Sir John Anderson, former Governor of Bengal, the nominee of the Unionist Associations of the Universities; Prof. A. Dewar Gibb, regius professor of law in the University of Glasgow, a Scottish Nationalist; Dr. Frances H. Melville, formerly mistress of Queen Margaret College, University of Glasgow, an Independent candidate; and Sir Peter Chalmers Mitchell, biologist and former secretary of the Zoological Society of London, standing as an Independent Progressive. Sir Peter Chalmers Mitchell is a graduate of the University of Aberdeen as well as of the University of Oxford, and he has maintained contact, during a life devoted to biological science and administration, with the arts and with educational developments in Great Britain and abroad. He was secretary of the Zoological Society of London for thirty-two years, and for a long period was leader writer and scientific correspondent of The Times. At a meeting of Scottish graduates in London he stated that the principle of university seats in Parliament is most difficult to defend if these are simply to be held by official nominees of the political parties, and that he considers it the duty of university electors to select the candidate with the best qualifications to advocate the services which the arts and sciences can give the nation. Sir Peter is particularly well qualified to present and uphold in the House of Commons the scientific outlook upon modern problems touched by science, and on this account his election to Parliament would be widely welcomed.

\section{Centenary of James Craig Watson}

ON January 28 the centenary occurs of the birth of the American astronomer James Craig Watson, whose name is recalled by the Watson Medal of the National Academy of Sciences. He was born in Elgin County, Canada, of American-parents, and at the age of fifteen years he entered the University of Michigan at Ann Arbor, and there came under the influence of the German astronomer Franz Brünnow (1821-91) who in 1854 had been appointed the first director of the Ann Arbor Observatory. Watson soon became an enthusiastic astronomer and on Brünnow's resignation in 1863 he succeeded him as director of the Observatory and as professor of astronomy. He held these positions until 1879, when he was appointed director of the Washburn Observatory at the University of Wisconsin, Madison, where he died suddenly on November 22, 1880, at the early age of forty-two years. Watson became known by his discovery of the minor planet Eurynome, which he first observed in 1863. Afterwards he discovered twenty-one other similar bodies. In 1867 he published a valuable work on theoretical astronomy which became a standard text-book. He was one of those who journeyed to Sicily to observe the solar eclipse of December 22, 1870, and four years later he visited Peking to observe the transit of Venus, for which event the astronomical world had established some forescore posts of observation at a cost of about a quarter of a million. In 1870, by which year he had discovered seven minor planets, Watson was awarded the Lalande Medal of the Paris Academy of Sciences.

\section{Royal Astronomical Society's Awards}

THE gold medal of the Royal Astronomical Society has been awarded to Dr. William Hammond Wright, director of the Lick Observatory, Mount Hamilton, California, for his studies of the spectra of gaseous nebulæ and of novæ and for his work on the photography of planets in light of different colours. A bronze ('Jackson-Gwilt') medal and gift have been awarded to Mr. P. M. Ryves for his observations of variable stars and other astronomical work, and also to Mr. F. J. Hargreaves for his contributions to astronomy. The investigations of Dr. W. H. Wright on the spectra of the gaseous nebulæ comprise : (1) measurements of wave-lengths and of intensities of nebular lines; (2) the study of the nebular nuclei ; (3) the investigation of the distribution of nebular radiations throughout the nebulæ. Dr. Wright was the first to realize the importance in these observations of accurate guiding, without allowing the object to drift along the slit to lengthen the lines, in order to study the spectra of the nuclei and to derive information with regard to the localization of lines in some of nebulæ. He has recently returned to the study of the spectra of planetary nebulæ in the ultraviolet, taking advantage of the extension to shorter wave-lengths made possible by the coating of the 36-inch mirror of the Crossley reflector with aluminium. Mr. Ryves has for many years been a most assiduous and accurate observer of variable 